\title{
Comparative study on the effects of substrate stiffness on cell morphology and focal adhesion expression between hMSCs and AFSCs
}

\author{
B Lowry ${ }^{*}$, R McCoy, F O'Brien \\ From International Conference for Healthcare and Medical Students 2011 \\ Dublin, Ireland. 4-5 November 2011
}

\section{Introduction}

Stiffness plays an important role in cell differentiation. Our project set out to compare the effects of substrate stiffness on cell morphology and focal adhesion expression between hMSCs and AFSCs.

\section{Methods}

We developed a novel technique for fabricating thin collagen-GAG films, which were further stiffened via DHT cross-linking techniques and/or EDAC cross-linking techniques. We cultured both cell types either on the fabricated collagen-GAG films or on glass microscope-slide cover-slips that had been coated in collagen-GAG slurry.

\section{Results}

Staining and imaging showed numerous clear focal adhesions had been formed for both cell types and the general morphology of the cells represented that of healthy cells with a flatly spread appearance when cultured on the glass cover-slips. On the collagen films, the cells showed poor focal adhesion formation and very diffuse staining, but no difference was observed as a function of crosslinking technique. Furthermore, the low stiffness also allowed the cells to contract giving them a narrow, elongated morphology.

\section{Conclusions}

In conclusion, from the limited number of cells observed in this study no qualitative differences were noted between AFSCs and MSCs in terms of focal adhesion expression or cell morphology on substrates of varying stiffness. However, focal adhesion expression levels were markedly

Royal College of Surgeons in Ireland

(C) 2012 Lowry et al; licensee BioMed Central Ltd. This is an Open Access article distributed under the terms of the Creative Commons Attribution License (http://creativecommons.org/licenses/by/2.0), which permits unrestricted use, distribution, and reproduction in any medium, provided the original work is properly cited. reduced for both cell types on the less stiff collagen-GAG films.

Published: 9 July 2012

\section{doi:10.1186/1753-6561-6-S4-O30}

Cite this article as: Lowry et al: Comparative study on the effects of substrate stiffness on cell morphology and focal adhesion expression between hMSCs and AFSCs. BMC Proceedings 2012 6(Suppl 4):O30.
Submit your next manuscript to BioMed Central and take full advantage of:

- Convenient online submission

- Thorough peer review

- No space constraints or color figure charges

- Immediate publication on acceptance

- Inclusion in PubMed, CAS, Scopus and Google Scholar

- Research which is freely available for redistribution 